\title{
Detection of Tick-Borne Pathogens of the Genera Rickettsia, Anaplasma and Francisella in Ixodes ricinus Ticks in Pomerania (Poland)
}

\author{
Lucyna Kirczuk $^{1}$ (D), Mariusz Piotrowski ${ }^{2}$ and Anna Rymaszewska ${ }^{2, *(D)}$ \\ 1 Department of Hydrobiology, Faculty of Biology, Institute of Biology, University of Szczecin, \\ Felczaka 3c Street, 71-412 Szczecin, Poland; lucyna.kirczuk@usz.edu.pl \\ 2 Department of Genetics and Genomics, Faculty of Biology, Institute of Biology, University of Szczecin, \\ Felczaka 3c Street, 71-412 Szczecin, Poland; mariusz.piotrowski@bio-space.pl \\ * Correspondence: anna.rymaszewska@usz.edu.pl
}

Citation: Kirczuk, L.; Piotrowski, M.; Rymaszewska, A. Detection of

Tick-Borne Pathogens of the Genera Rickettsia, Anaplasma and Francisella in Ixodes ricinus Ticks in Pomerania (Poland). Pathogens 2021, 10, 901. https://doi.org/10.3390/ pathogens10070901

Academic Editor: Vett Lloyd

Received: 2 June 2021

Accepted: 13 July 2021

Published: 15 July 2021

Publisher's Note: MDPI stays neutral with regard to jurisdictional claims in published maps and institutional affiliations.

Copyright: () 2021 by the authors. Licensee MDPI, Basel, Switzerland. This article is an open access article distributed under the terms and conditions of the Creative Commons Attribution (CC BY) license (https:// creativecommons.org/licenses/by/ $4.0 /)$.

\begin{abstract}
Tick-borne pathogens are an important medical and veterinary issue worldwide. Environmental monitoring in relation to not only climate change but also globalization is currently essential. The present study aimed to detect tick-borne pathogens of the genera Anaplasma, Rickettsia and Francisella in Ixodes ricinus ticks collected from the natural environment, i.e., recreational areas and pastures used for livestock grazing. A total of 1619 specimens of I. ricinus were collected, including ticks of all life stages (adults, nymphs and larvae). The study was performed using the PCR technique. Diagnostic gene fragments msp2 for Anaplasma, gltA for Rickettsia and tul4 for Francisella were amplified. No Francisella spp. DNA was detected in I. ricinus. DNA of A. phagocytophilum was detected in $0.54 \%$ of ticks and Rickettsia spp. in $3.69 \%$. Nucleotide sequence analysis revealed that only one species of Rickettsia, R. helvetica, was present in the studied tick population. The present results are a part of a large-scale analysis aimed at monitoring the level of tick infestation in Northwest Poland.
\end{abstract}

Keywords: Rickettsia helvetica; tick-borne pathogens; Anaplasma phagocytophilum

\section{Introduction}

Blood-sucking arthropods, such as ticks, insects and mites, are a group that plays a special role in the spread of many species of obligate intracellular microorganisms. Among them, hard ticks of the family Ixodidae, are very important as cosmopolitan vectors of pathogens that cause disease in humans and domestic animals. Ixodes ricinus is one of the most important species of hard ticks that plays a significant role in the transmission of bacteria, viruses and protozoa. The pathogens transmitted by ticks include bacteria of the genera Borrelia, Anaplasma, Ehrlichia, Rickettsia and Francisella and protozoa of the genera Babesia and Theileria [1,2].

Bacteria of the genera Anaplasma and Rickettsia belong to obligate intracellular pathogens [1,2], while Francisella is a facultative intracellular pathogen [3]. All are pathogens of vertebrates and have a wide range of species as their reservoirs. These host species include, among others, deer, wild boar, small rodents and birds [4-7].

Microorganisms belonging to the family Anaplasmataceae are intracellular alpha-1 proteobacteria that multiply in the vacuoles of eukaryotic cells. According to the latest classification, this family includes five genera-Anaplasma, Ehrlichia, Aegyptianella, Neorickettsia and Wolbachia - of which Anaplasma and Ehrlichia are considered as the most pathogenic [1,8]. Anaplasma phagocytophilum causes human granulocytic anaplasmosis (HGA) in humans and tick-borne fever (TBF) in many domestic animals, mainly small ruminants, horses and dogs [2,6].

Bacteria belonging to the genus Rickettsia comprise two historical groups: the typhus group (TG) and the spotted fever group (SFG), and two recently separated new groups: the transitional group (TRG; R. felis, R. akari and R. australis), and the ancestral group (AG; 
R. bellii and R. canadensis) $[9,10]$. For Rickettsia, ticks are not only efficient vectors but also competent reservoirs. Rickettsioses, like anaplasmosis, pose an important medical and veterinary problem. In the description of the disease, the classical symptomatic triad of fever, rash and headache, which are the main clinical signs to diagnose rickettsiosis but are also observed in other tick-borne diseases, is given as a delineation. Each instance of rickettsiosis has been shown to have specific characteristics, including severity. Rickettsioses can be mild, severe or even fatal $[7,10]$.

Tularemia is an acute zoonotic disease caused by the Gram-negative aerobic bacillus Francisella tularensis. There are four subspecies of $F$. tularensis, two of which are considered pathogenic for humans and animals: type A, F. tularensis subsp. Tularensis, and type B, F. tularensis subsp. holarctica. Type A is highly infectious and virulent, and therefore, remains an epidemiological issue in some countries. Type B is milder and occurs mainly in Europe and Asia. In Europe, type B has most been reported in Scandinavian countries, where it has remained stable since 2006 [5,11,12]. In Poland, there has been a small but stable increase in the incidence of tularemia. The first case of tularemia was diagnosed in 1949, and since then, more than 600 cases have been reported, mainly in the northeastern and northwestern regions of the country. In most cases, the infection was transmitted by ixodid ticks or by direct contact with infected animals [13]. Furthermore, members of the Francisella genus are highly pathogenic with a potential risk of bioterrorism. Francisella tularensis, along with Bacillus anthracis, Yersinia pestis and Brucella sp., is among the microorganisms that can be used for bioterrorist attacks; therefore, strict environmental monitoring is required to take appropriate and timely action [14].

The incidence of tick-borne diseases in Europe is lower than that reported globally. A feature of many of these infections in the Old Continent is their relatively mild course. The main symptoms of these infections are fever, headache and muscle and joint pains, which resemble the common cold. However, monitoring of ticks reveals the presence of pathogens, which is not reflected in the dynamics of human infections. Hence, it appears that tick-borne diseases may be underdiagnosed or underreported in European countries [15]. In Poland, as in many other countries, it is mandatory to report and register tick-borne diseases $[15,16]$.

Despite many years of research, the topic of screening of questing ticks that are major vectors of tick-borne pathogens is still relevant. Molecular research of ticks collected from vegetation is part of environmental monitoring. Information on ticks infected by pathogens is important for medical and veterinary doctors. Monitoring of ticks for the presence of pathogens facilitates the diagnosis of humans and animals. The present study aimed to estimate the infection of the castor bean tick I. ricinus captured from the environment by A. phagocytophilum, Rickettsia spp. and Francisella spp. The areas designated for sample collection were recreational sites and meadows used for livestock grazing.

\section{Results}

A total of 1682 I. ricinus ticks (111 females, 68 males, 1008 nymphs and 495 larvae) were collected from all sites (Figure 1, Table 1). None of the sites explored showed the presence of Francisella spp. DNA in I. ricinus. Overall, higher infection of ticks by Rickettsia than by A. phagocytophilum was observed. For Rickettsia, infection was found in two individuals (0.76\%) in Lubieszyn and $24(5.74 \%)$ in Imno. Anaplsma phagocytophilum was not found in Lubieszyn, while in Imno and Świerznica, anaplasma DNA was detected in four individuals, of 0.84 and $0.95 \%$, respectively. In Ciemnik, only one nymph $(0.19 \%)$ of 524 I. ricinus individuals was positive for A. phagocytophilum. Detailed infection data are provided in Table 2. Only one individual, a nymph of I. ricinus $(0.06 \%)$, collected at the Świerznica site, was found to be co-infected with A. phagocytophilum and R. helvetica.

The presence of two nucleotide variants was observed in A. phagocytophilum, which has previously been described in ticks and has been reported to GenBank by the author [17]. The sequences of the $m s p 2$ amplified fragment are identical to those of accession numbers DQ105670 (host Capreolus capreolus) and DQ105673 (host I. ricinus). Due to the identity of the 
nucleotide sequences generated in this study, they were not submitted to GenBank. Polish A. phagocytophilum sequences for the $m s p 2$ gene fragment in comparison with sequences from farm animals, ticks (from Europe) and a human (US patient) showed an identity of more than $99 \%$ (data not shown).

For Rickettsia, only one species, R. helvetica, was found based on the nucleotide sequence of the gltA gene, which is a good tool for taxonomic identification of bacteria [18]. Analysis of the $h t r A$ gene confirmed species affiliation for the studied isolates. No genetic variation was observed among the analyzed glt $A$ and $h t r A$ genes. On the dendrogram, the obtained sequences for $R$. helvetica clustered with other sequences of this species obtained from ticks or reservoir species (rodents and dogs) in European countries (Figure 2).

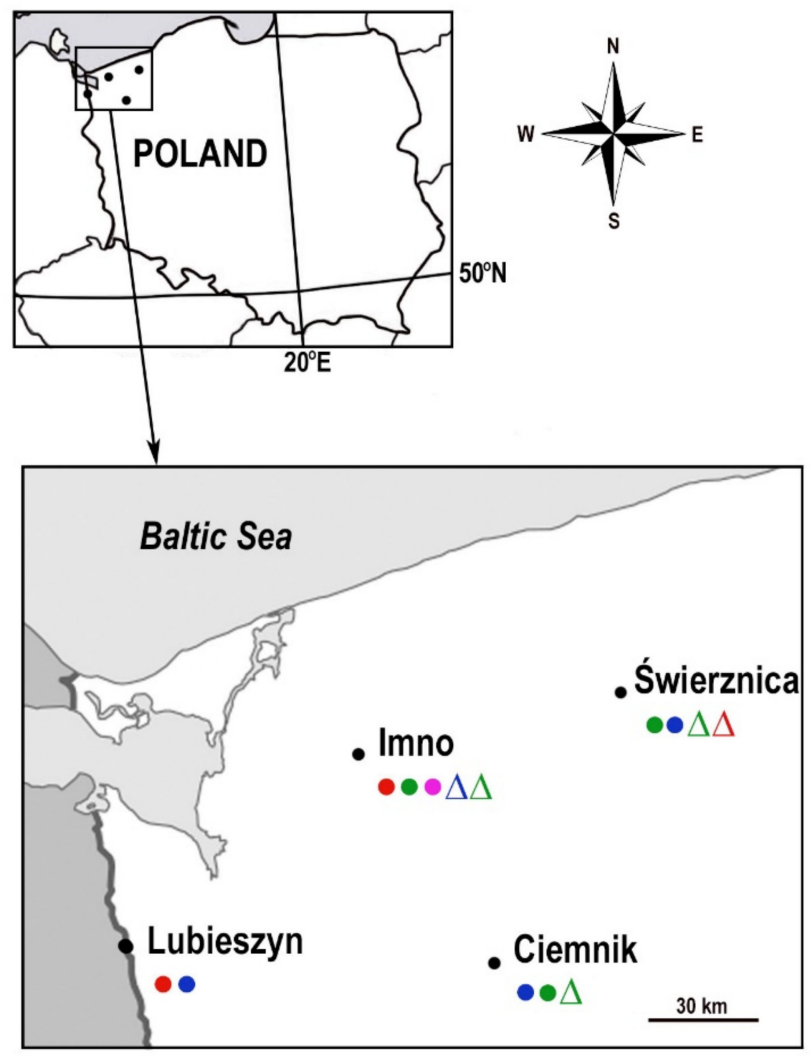

Figure 1. Collection sites of Ixodes ricinus. Tick infection: $\bullet$ R. helvetica (male ticks), $\bullet$ R. helvetica (female), $\bullet R$. helvetica (nymph), $\bullet R$. helvetica (larvae); $\Delta A$. phagocytophilum (male), $\Delta A$. phagocytophilum (female), $\triangle$ A. phagocytophilum (nymph).

Table 1. Numbers and representation of development of all stages of Ixodes ricinus examined in the study.

\begin{tabular}{|c|c|c|c|c|c|}
\hline Site & Number of Ticks & Female $n / \%$ & Male $\mathrm{n} / \%$ & Nymph n/\% & Larvae $n / \%$ \\
\hline $\begin{array}{c}\text { Świerznica } \\
21 / 4.42\end{array}$ & 475 & $14 / 2.9$ & $15 / 3.16$ & $252 / 53.05$ & $194 / 40.84$ \\
\hline $\begin{array}{c}\text { Ciemnik } \\
15 / 2.86\end{array}$ & 524 & $35 / 6.68$ & $29 / 5.53$ & $276 / 52.67$ & $184 / 35.11$ \\
\hline $\begin{array}{c}\text { Imno } \\
24 / 5.71\end{array}$ & 420 & $55 / 13.09$ & $10 / 2.38$ & $252 / 60$ & $103 / 24.52$ \\
\hline $\begin{array}{c}\text { Lubieszyn } \\
2 / 0.76\end{array}$ & 263 & $7 / 2.66$ & $14 / 5.32$ & $228 / 86.69$ & $14 / 5.32$ \\
\hline Total & 1682 & $111 / 6.60$ & $68 / 4.04$ & $1008 / 59.93$ & $495 / 29.43$ \\
\hline
\end{tabular}


Table 2. Infection of ticks by pathogens of the genera Rickettsia and Anaplasma.

\begin{tabular}{|c|c|c|c|c|c|c|c|c|c|c|}
\hline \multirow{2}{*}{$\begin{array}{l}\text { Number } \\
\text { of Ticks }\end{array}$} & \multicolumn{2}{|c|}{ Site/Infection } & \multicolumn{2}{|c|}{ Female $(n / \%) \bullet \Delta$} & \multicolumn{2}{|c|}{ Male $(\mathrm{n} / \%) \bullet \Delta$} & \multicolumn{2}{|c|}{ Nymph $(\mathrm{n} / \%) \bullet \Delta$} & \multicolumn{2}{|c|}{ Larvae $(n / \%) \bullet \Delta$} \\
\hline & $\begin{array}{c}\text { Ric } \\
\text { n/\%PCR+ }\end{array}$ & $\begin{array}{c}\text { Aph } \\
\text { n/\%PCR+ }\end{array}$ & $\underset{\text { n/\%PCR+ }}{\text { Ric }}$ & $\begin{array}{c}\text { Aph } \\
\text { n/\%PCR+ }\end{array}$ & $\begin{array}{c}\text { Ric } \\
\text { n/\%PCR+ }\end{array}$ & $\begin{array}{c}\text { Aph } \\
\text { n/\%PCR+ }\end{array}$ & $\begin{array}{c}\text { Ric } \\
\text { n/\%PCR+ }\end{array}$ & $\begin{array}{c}\text { Aph } \\
\text { n/\%PCR+ }\end{array}$ & $\begin{array}{c}\text { Ric } \\
\text { n/\%PCR+ }\end{array}$ & $\begin{array}{c}\text { Aph } \\
\text { n/\%PCR+ }\end{array}$ \\
\hline \multirow[b]{2}{*}{457} & \multicolumn{2}{|c|}{ Świerznica } & & & & & & & & \\
\hline & $21 / 4.42$ & $4 / 0.84$ & 0 & $1 / 7.14$ & $3 / 20.0$ & 0 & $18 / 7.14$ & 3/1.19 & 0 & nt \\
\hline \multirow{2}{*}{524} & \multicolumn{2}{|c|}{ Ciemnik } & & & $4 / 127$ & & $11 / 200$ & & & \\
\hline & $15 / 2.86$ & $1 / 0.19$ & 0 & 0 & 4/13.7 & 0 & $11 / 3.99$ & $1 / 0.36$ & 0 & nt \\
\hline \multirow{2}{*}{420} & \multicolumn{2}{|c|}{ Imno } & & & & & & & & \\
\hline & $24 / 5.71$ & $4 / 0.95$ & 1/1.82 & 0 & 0 & $2 / 20.0$ & $22 / 8.73$ & $2 / 0.79$ & $1 / 0.97$ & nt \\
\hline \multirow[b]{2}{*}{263} & \multicolumn{2}{|c|}{ Lubieszyn } & $1 / 1420$ & & $1 / 714$ & & 0 & & & \\
\hline & $2 / 0.76$ & $0 / 0.84$ & $1 / 14.29$ & 0 & $1 / 7.14$ & 0 & 0 & 0 & 0 & nt \\
\hline 1682 & Total & & $2 / 1.80$ & $1 / 0.90$ & $8 / 11.76$ & $2 / 2.94$ & $51 / 1.80$ & $6 / 0.90$ & $1 / 0.2$ & nt \\
\hline
\end{tabular}

Abbreviations: Ric—Rickettsia helvetica; Aph-Anaplasma phagocytophiulm; nt—not tested.

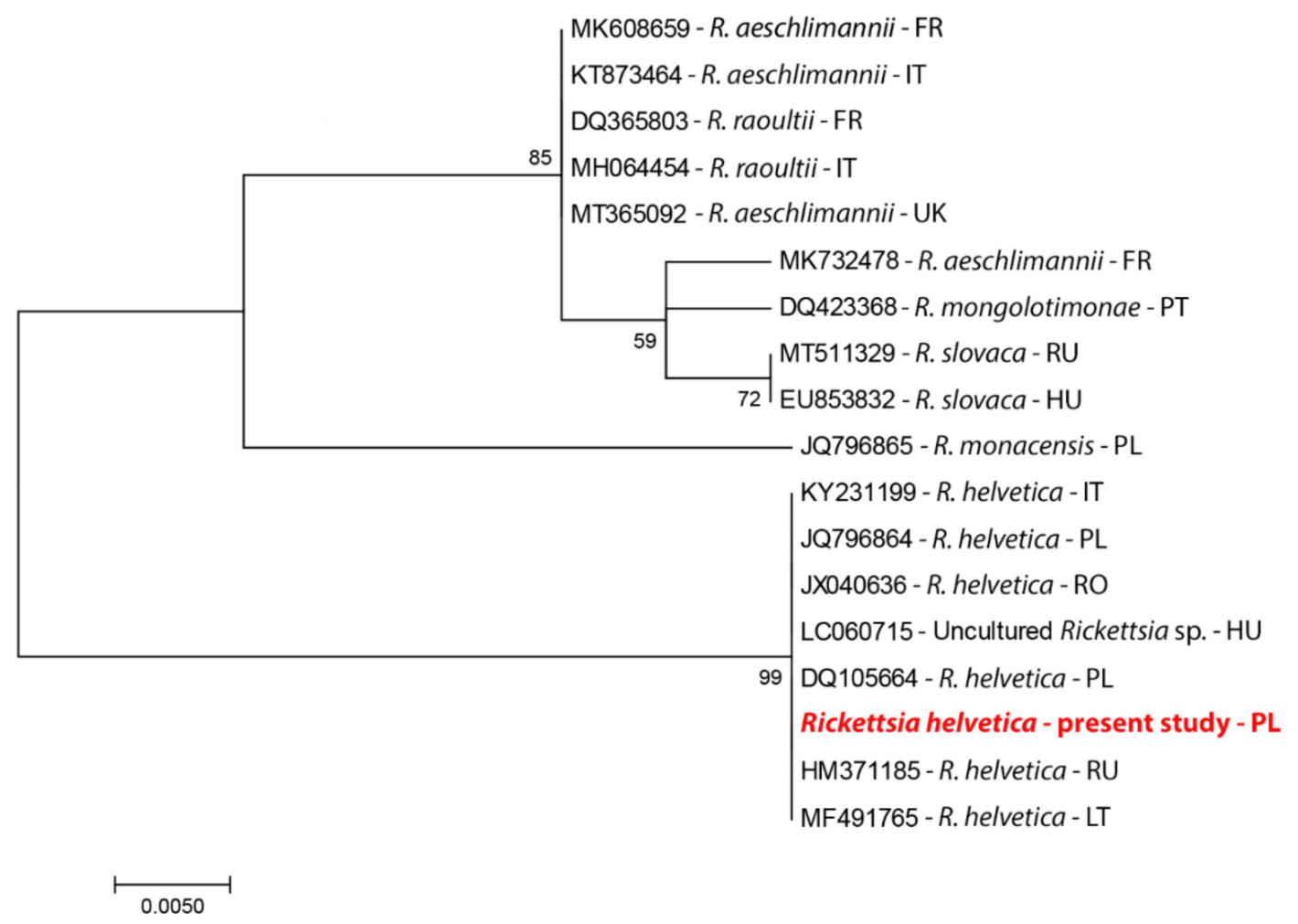

Figure 2. A phylogram constructed on the basis of the glt $A$ gene. The analysis was performed on species of the genus Rickettsia, available from GenBank (country codes: https:/ / www.pit.pl/intrastat/kody-panstw-intrastat-922638 accessed on 15 May 2021).

\section{Discussion}

In Poland, the most commonly reported tick-borne diseases include Lyme disease and tick-borne encephalitis. Data from the National Institute of Hygiene (NIH) in 2019 show that 20,630 cases of Lyme borreliosis were registered, of which 1701 people were hospitalized. Moreover, in 2019, 265 cases of tick-borne encephalitis were registered, 68 more than in 2018. In contrast, 21 cases of tularemia (16 hospitalized) or four cases of rickettsiosis were reported in 2019, i.e., five less than in the previous year (http:/ / wwwold. pzh.gov.pl accessed on 15 May 2021).

In Poland, epidemic outbreaks of tularemia occur mainly in the north and east of the country, i.e., in the region of Szczecin, Gdańsk, Bydgoszcz and Białystok. According 
to the Polish National Institute of Hygiene (NIH), the highest number of cases [8] was reported in Western Pomerania, and isolated cases were common in other regions. The area of Pomerania covered by the screening study did not show any Francisella sp. DNA in ticks. Wójcik-Falata et al. [19] studied I. ricinus and Dermacentor reticulatus ticks and revealed the presence of $F$. tularensis subspecies holarctica only in Dermacentor and at a very low level, only $0.2 \%$. The role of I. ricinus in vectoring Francisella sp. is controversial. Transmission of these bacteria by I. ricinus has not been confirmed in Hungary, Luxembourg or France [20-23]. However in central Germany ranged from 1.2-1.5\% for ticks feeding on birds and rodents to $1.6 \%$ for host-seeking ticks [4]. Higher levels of I. ricinus infection with F. tularensis were reported in Serbia (3.8\%) [24] and in south-western Germany (8.4\%); Some authors also indicated a higher level of infection for ticks of the genus Dermacentor [25,26]. On the basis of the analysis of the epidemiological status of tularemia in European countries, it seems that ticks do not play an important role in the transmission of F. tularensis, and infections of humans or domestic animals result mainly from contact with infected rabbits, hares, rodents or squirrels [5].

Regarding both granulocytic anaplasmosis and rickettsioses caused by SFG rickettsieae, the occurrence of the diseases in a given area is primarily associated with contact with infected ticks. In Europe, infection of ticks by A. phagocytophilum is low, ranging from $0.6 \%$ to $3 \%[20,21,27]$.

In the present study, the infection of ticks by both pathogens, A. phagocytophilum and $R$. helvetica, in northwestern Poland is comparable to the results reported in other European countries. In this part of Europe, ticks are mainly infected with A. phagocytophium and at low levels. Several species of Rickettsia spp. may occur, but the most common one is R. helvetica. In our study, we expected to detect two species of Rickettsia from the SFG, especially because the presence of $R$. monacensis in questing ticks of I. ricinus collected from the forests of Western Pomerania was reported [28]. However, nucleotide sequence analysis revealed that only $R$. helvetica was present in the examined tick populations from four sites in Western Pomerania. The latest research by Kowalec et al. [29] and Michalski et al. [30] conducted in I. ricinus ticks collected from central and northeastern Poland showed the presence of the species $R$. raoulti and the novel "Candidatus Rickettsia mendelii" in these ticks, apart from $R$. helvetica and $R$. monacensis. The authors' current research, unpublished (material harvested in 2019-2020), in ticks collected from urbanized areas of Western Pomerania has not yet revealed the presence of species other than $R$. helvetica and $R$. monacensis.

Comparison of sequences obtained from A. phagocytophilum revealed high identity with sequences previously obtained from isolates from host-seeking ticks and ticks parasitized on wildlife $[6,17]$. Previous studies suggested that the nucleotide sequences of the two A. phagocytophilum variants detected did not cluster with the $m s p 2$ gene sequences isolated from patients with suspected anaplasmosis.

As observed for tularemia, epidemiological data for the other two tick-borne diseases (spotted fever and anaplasmosis) do not correlate with the infection status of ticks. A very low incidence among humans has been observed, and at the same time, studies indicate infection of ticks, as well as the presence of antibodies in humans and animals considered potential reservoir species for these pathogens [31-33].

In Poland, over the past few years, rickettsiosis has been extremely rare, with less than 10 cases per year reported by the National Institute of Hygiene (http:/ / wwwold.pzh.gov.pl accessed on 15 May 2021). However, tests for the presence of antibodies to tick-borne pathogens indicate frequent contact with bacteria of the genera Rickettsia and Anaplasma. The cases of tick-borne diseases with non-specific symptoms are underestimated. Information about a tick infection can be helpful for doctors and veterinarians. Therefore, regular monitoring of ticks should be carried out and it should cover urban areas.

In summary, it should be emphasized that I. ricinus ticks are a vector for $R$. helvetica and A. phagocytophilum in northwestern Poland. The search should be extended to include other transmitting or reservoir species for this pathogen. 


\section{Materials and Methods}

\subsection{Characteristics of the Collection Sites}

Questing ticks were collected in July-August 2012 using the flagging method from grasslands in Western and Central Pomerania (Poland) (Figure 1), located near the villages of Świerznica $\left(53.8597^{\circ} \mathrm{N}, 15.9962^{\circ} \mathrm{E}\right)$, Ciemnik $\left(53.3833^{\circ} \mathrm{N}, 15.5667^{\circ} \mathrm{E}\right), \operatorname{Imno}\left(53.5500^{\circ}\right.$ $\left.\mathrm{N}, 14.9333^{\circ} \mathrm{E}\right)$ and Lubieszyn $\left(53.4494^{\circ} \mathrm{N}, 14.3892^{\circ} \mathrm{E}\right)$. The areas selected for collection are characterized by high natural values. These places abound in green areas, including forests rich in vegetation, mainly deciduous and mixed forests. The village of Świerznica is located in the wooded valley of the Świerznica river, an area included in the special habitat protection area "Dorzecze Parsety". According to the Central Register of Nature Protection Forms (CRFOP) (data from 30 June 2017), there are six forms of nature protection in the area of Ciemnik village: Krzemieńskie Źródliska nature reserve, four nature monuments and Ostoja Inska (special bird protection area-Natura 2000). The first and currently the largest studied farm of Shetland ponies in Poland is located in Imno. In the commune of Dobra, in which Lubieszyn is located (a hamlet of the village of Wawelnica with a Polish-German border crossing), there are abundant forests covering the Wkrzańska Forest and the surroundings of the Świdwie Bird Nature Reserve (a breeding site of the white eagle). All these places serve as recreational sites for inhabitants and visitors, and they are particularly attractive as tourist sites for amateur walkers and cyclists who visit. Apart from value for tourism, a large part of the land in these regions is used for agricultural purposes and pastures where cattle and small ruminants, mainly goats, graze.

\subsection{Sample Preparation and Molecular Analysis}

Ixodes ricinus ticks were collected from vegetation using the flagging method, by sweeping vegetation with flannel flags to a height of $1 \mathrm{~m}$. The species and stages of the ticks were identified with the use of zoological keys [34].

A total of 1619 individuals of I. ricinus comprising all life stages-larvae, nymphs and adults-were collected. Details of the collected study material are included in Table 1. Ticks were homogenized (TissueLyser LT, QIAGEN) and DNA was isolated from each individual by the phenol-chloroform method [35]. Pools (five isolates each) were prepared for screening, following which all positive pools (PCR $+=$ presence of pathogen) were retested for individuals.

Ticks were screened for the presence of DNA of $A$. phagocytophilum, Rickettsia spp. and Francisella spp. The following markers were used for analysis: msp2 (gene-encoding polymorphic major outer-membrane protein) for A. phagocytophilum, with primers msp3f, msp3r [36] and gltA (gene-encoding citrate synthase), for Rickettsia, with primers RpCs877, RpCs1258 [18] and tul4, and for F. tularensis, with primers tul4-435 and tul4-863 (17-kDa lipoprotein gene primers) [37]. The expected product lengths were $334 \mathrm{bp}$ (msp2), $382 \mathrm{bp}$ ( $g l t A)$ and $410 \mathrm{bp}(t u l 4)$, respectively. For additional species characterization for Rickettsia spp., reactions were performed for positive samples using the $h t r A$ marker encoding a $17 \mathrm{kDa}$ membrane protein [38].

All stages of ticks were tested for pathogen DNA. PCR for A. phagocytophilum was not performed only for I. ricinus larvae because it has previously been demonstrated that Anaplasma species do not spread through transovarial transmission [1,2].

PCR analysis used Color OptiTaq DNA Polymerase (EUR $\times$ Ltd., Gdańsk, Poland). The PCR reaction mixture contained PCR Buffer, $2.0 \mathrm{mM} \mathrm{MgCl} 2,2.0 \mathrm{mM}$ of each dNTP mix, $10 \mathrm{pmol} / \mu \mathrm{L}$ of forward and reverse primers and $0.2 \mathrm{U}$ Taq Polymerase $/ 10 \mu \mathrm{L}$ master mix. The thermal-time profile was in accordance with the requirements indicated by the manufacturer.

\subsection{DNA Sequencing and Phylogenetic Analysis}

Positive samples were sequenced for adults and larvae, and of all "PCR+" nymphs, 15 were selected for sequencing. Because no differences were found in the analyzed gene 
fragments, the remaining positive samples were not sequenced. The positive samples were sequenced at Macrogen Europe (Amsterdam, The Netherlands).

Bioinformatic analyses were performed for the obtained nucleotide sequences using BLAST software and MEGA. Only the original sequences were submitted to GenBank. The Maximum Likelihood method, implemented in MEGA X, was used for phylogenetic analyses [39]. The "best fit" substitution model was calculated using the Model Test implemented in MEGA X (selected: Tamura's 3-parameter model) [40].

Accession numbers: DNA sequences MZ146785 (R. helvetica, gltA) and MZ146785 (R. helvetica, htrA).

Author Contributions: Conceptualization, A.R.; methodology, A.R.; software, A.R.; validation, A.R., L.K. and M.P.; formal analysis, A.R. and L.K.; investigation, A.R., L.K. and M.P.; resources, A.R.; data curation, A.R. and M.P.; writing—original draft preparation, A.R.; writing, A.R. and L.K.; visualization, A.R. and L.K.; supervision, A.R.; project administration, A.R.; funding acquisition, A.R. and L.K. All authors have read and agreed to the published version of the manuscript.

Funding: The study was conducted with the funds of the US Institute of Biology. This research received no external funding.

Institutional Review Board Statement: Not applicable.

Informed Consent Statement: Not applicable.

Data Availability Statement: https:/ / www.ncbi.nlm.nih.gov/genbank accessed date 15 May 2021.

Conflicts of Interest: The authors declare no conflict of interest.

\section{References}

1. Dumler, J.S.; Barbet, A.F.; Bekker, C.P.; Dasch, G.A.; Palmer, G.H.; Ray, S.C.; Rikihisa, Y.; Rurangirwa, F.R. Reorganization of genera in the families Rickettsiaceae and Anaplasmataceae in the order Rickettsiales: Unification of some species of Ehrlichia with Anaplasma, Cowdria with Ehrlichia and Ehrlichia with Neorickettsia, descriptions of six new species combinations and designation of Ehrlichia equi and 'HGE agent' as subjective synonyms of Ehrlichia phagocytophila. Int. J. Syst. Evol. Microbiol. 2001, 51, $2145-2165$. [CrossRef]

2. Rikihisa, Y. Mechanisms of obligatory intracellular infection with Anaplasma phagocytophilum. Clin. Microbiol Rev. 2011, 24, 469-489. [CrossRef] [PubMed]

3. Müller, W.; Bocklisch, H.; Schüler, G.; Hotzel, H.; Neubauer, H.; Otto, P. Detection of Francisella tularensis subsp. holarctica in a European brown hare (Lepus europaeus) in Thuringia, Germany. Vet. Microbiol. 2007, 123, 225-229. [CrossRef]

4. Franke, J.; Fritzsch, J.; Tomaso, H.; Straube, E.; Dorn, W.; Hildebrandt, A. Coexistence of pathogens in host-seeking and feeding ticks within a single natural habitat in Central Germany. Appl. Environ. Microbiol. 2010, 76, 6829-6836. [CrossRef] [PubMed]

5. Hestvik, G.; Warns-Petit, E.; Smith, L.A.; Fox, N.J.; Uhlhorn, H.; Artois, M.; Hannant, D.; Hutchings, M.R.; Mattsson, R.; Yon, L.; et al. The status of tularemia in Europe in a one-health context: A review. Epidemiol. Infect. 2015, 143, 2137-2160. [CrossRef] [PubMed]

6. Adamska, M. The role of different species of wild ungulates and Ixodes ricinus ticks in the circulation of genetic variants of Anaplasma phagocytophilum in a forest biotope in north-western Poland. Ticks Tick Borne Dis. 2020, 11, 101-465. [CrossRef] [PubMed]

7. Piotrowski, M.; Rymaszewska, A. Expansion of tick-borne rickettsioses in the world. Microorganisms 2020, 8, 1906. [CrossRef] [PubMed]

8. Kernif, T.; Leulmi, H.; Raoult, D.; Parola, P. Emerging tick-borne bacterial pathogens. Microbiol. Spectr. 2016, 4. [CrossRef]

9. Londoño, A.F.; Acevedo-Gutiérrez, L.Y.; Marín, D.; Contreras, V.; Díaz, F.J.; Valbuena, G.; Labruna, M.B.; Hidalgo, M.; Arboleda, M.; Mattar, S.; et al. Human prevalence of the spotted fever group (SFG) rickettsiae in endemic zones of Northwestern Colombia. Ticks Tick Borne Dis. 2017, 8, 477-482. [CrossRef]

10. Gillespie, J.J.; Williams, K.; Shukla, M.; Snyder, E.E.; Nordberg, E.K.; Ceraul, S.M.; Dharmanolla, C.; Rainey, D.; Soneja, J.; Shallom, J.M.; et al. Rickettsia phylogenomics: Unwinding the intricacies of obligate intracellular life. PLoS ONE 2008, 3, e2018. [CrossRef]

11. Otto, P.; Kohlmann, R.; Müller, W.; Julich, S.; Geis, G.; Gatermann, S.G.; Peters, M.; Wolf, P.J.; Karlsson, E.; Forsman, M.; et al. Hare-to-human transmission of Francisella tularensis subsp. holarctica, Germany. Emerg. Infect. Dis. 2015, 21, 153-155. [CrossRef] [PubMed]

12. Seiwald, S.; Simeon, A.; Hofer, E.; Weiss, G.; Bellmann-Weiler, R. Tularemia Goes West: Epidemiology of an emerging infection in Austria. Microorganisms 2020, 8, 1597. [CrossRef]

13. Yanushevych, M.; Komorowska-Piotrowska, A.; Feleszko, W. Tularaemia-A forgotten disease? Own experience. Med. Wieku Rozwoj 2013, 17, 355-359. 
14. Zasada, A.A.; Gierczyński, R.; Rzeczkowska, M.; Formińska, K.; Zacharczuk, K.; Rastawicki, W. Detection and identification of highly pathogenic bacteria within the framework of the EQADeBa project-Part I: Samples containing living pathogens. Przegl. Epidemiol. 2011, 65, 401-407. [PubMed]

15. Matei, I.A.; Estrada-Peña, A.; Cutler, S.J.; Vayssier-Taussat, M.; Varela-Castro, L.; Potkonjak, A.; Zeller, H.; Mihalca, A.D. A review on the eco-epidemiology and clinical management of human granulocytic anaplasmosis and its agent in Europe. Parasites Vectors 2019, 12, 599. [CrossRef]

16. Mączka, I.; Roguska, U.; Tylewska-Wierzbanowska, S. Occurrence of rickettsial infection in Poland in 2006-2012. Przegl. Epidemiol. 2013, 67, 721-723.

17. Rymaszewska, A. Variability within the msp2 gene in populations of Anaplasma phagocythopilum. Folia Biol. 2010, 56, $269-275$.

18. Nilsson, K.; Lindquist, O.; Liu, A.J.; Jaenson, T.G.; Friman, G.; Påhlson, C. Rickettsia helvetica in Ixodes ricinus ticks in Sweden. J. Clin. Microbiol. 1999, 37, 400-403. [CrossRef]

19. Wójcik-Fatla, A.; Zając, V.; Sawczyn, A.; Cisak, E.; Sroka, J.; Dutkiewicz, J. Occurrence of Francisella spp. in Dermacentor reticulatus and Ixodes ricinus ticks collected in eastern Poland. Ticks Tick Borne Dis. 2015, 6, 253-257. [CrossRef]

20. Reye, A.L.; Hübschen, J.M.; Sausy, A.; Muller, C.P. Prevalence and seasonality of tick-borne pathogens in questing Ixodes ricinus ticks from Luxembourg. Appl. Environ. Microbiol. 2010, 76, 2923-2931. [CrossRef] [PubMed]

21. Egyed, L.; Elő, P.; Sréter-Lancz, Z.; Széll, Z.; Balogh, Z.; Sréter, T. Seasonal activity and tick-borne pathogen infection rates of Ixodes ricinus ticks in Hungary. Ticks Tick Borne Dis. 2012, 3, 90-94. [CrossRef] [PubMed]

22. Bonnet, S.; de la Fuente, J.; Nicollet, P.; Liu, X.; Madani, N.; Blanchard, B.; Maingourd, C.; Alongi, A.; Torina, A.; Fernández de Mera, I.G.; et al. Prevalence of tick-borne pathogens in adult Dermacentor spp. ticks from nine collection sites in France. Vector Borne Zoonot Dis. 2013, 13, 226-236. [CrossRef] [PubMed]

23. Kreizinger, Z.; Hornok, S.; Dán, A.; Hresko, S.; Makrai, L.; Magyar, T.; Bhide, M.; Erdélyi, K.; Hofmann-Lehmann, R.; Gyuranecz, M. Prevalence of Francisella tularensis and Francisella-like endosymbionts in the tick population of Hungary and the genetic variability of Francisella-like agents. Vector Borne Zoonot. Dis. 2013, 13, 160-163. [CrossRef]

24. Milutinović, M.; Masuzawa, T.; Tomanović, S.; Radulović, Z.; Fukui, T.; Okamoto, Y. Borrelia burgdorferi sensu lato, Anaplasma phagocytophilum, Francisella tularensis and their co-infections in host-seeking Ixodes ricinus ticks collected in Serbia. Exp. Appl. Acarol. 2008, 45, 171-183. [CrossRef]

25. Gehringer, H.; Schacht, E.; Maylaender, N.; Zeman, E.; Kaysser, P.; Oehme, R.; Pluta, S.; Splettstoesser, W.D. Presence of an emerging subclone of Francisella tularensis holarctica in Ixodes ricinus ticks from south-western Germany. Ticks Tick Borne Dis. 2013, 4, 93-100. [CrossRef] [PubMed]

26. Michelet, L.; Bonnet, S.; Madani, N.; Moutailler, S. Discriminating Francisella tularensis and Francisella-like endosymbionts in Dermacentor reticulatus ticks: Evaluation of current molecular techniques. Vet. Microbiol. 2013, 163, 399-403. [CrossRef] [PubMed]

27. Laaksonen, M.; Klemola, T.; Feuth, E.; Sormunen, J.J.; Puisto, A.; Mäkelä, S.; Penttinen, R.; Ruohomäki, K.; Hänninen, J.; Sääksjärvi, I.E.; et al. Tick-borne pathogens in Finland: Comparison of Ixodes ricinus and I. persulcatus in sympatric and parapatric areas. Parasite Vector 2018, 11, 556. [CrossRef]

28. Rymaszewska, A.; Piotrowski, M. Use of DNA sequences for Rickettsia identification in Ixodes ricinus ticks: The first detection of Rickettsia monacensis in Poland. Microbes Infect. 2013, 15, 140-146. [CrossRef] [PubMed]

29. Kowalec, M.; Szewczyk, T.; Welc-Falęciak, R.; Siński, E.; Karbowiak, G.; Bajer, A. Rickettsiales occurrence and co-occurrence in Ixodes ricinus ticks in natural and urban areas. Microb. Ecol. 2019, 77, 890-904. [CrossRef]

30. Michalski, M.M.; Kubiak, K.; Szczotko, M.; Dmitryjuk, M. Tick-borne pathogens in ticks collected from wild ungulates in North-Eastern Poland. Pathogens 2021, 10, 587. [CrossRef]

31. Žákovská, A.; Bártová, E.; Pittermannová, P.; Budíková, M. Antibodies related to Borrelia burgdorferi sensu lato, Coxiella burnetii, and Francisella tularensis detected in serum and heart rinses of wild small mammals in the Czech Republic. Pathogens 2021, 10, 419. [CrossRef]

32. Wächter, M.; Wölfel, S.; Pfeffer, M.; Dobler, G.; Kohn, B.; Moritz, A.; Pachnicke, S.; Silaghi, C. Serological differentiation of antibodies against Rickettsia helvetica, R. raoultii, R. slovaca, R. monacensis and R. felis in dogs from Germany by a microimmunofluorescent antibody test. Parasite Vectors 2015, 23, 126. [CrossRef]

33. Jansen, A.; La Scola, B.; Raoult, D.; Lierz, M.; Wichmann, O.; Stark, K.; Schneider, T. Antibodies against Rickettsia spp. in hunters, Germany. Emerg. Infect. Dis. 2008, 14, 1961-1963. [CrossRef]

34. Nowak-Chmura, M. The Fauna of Ticks (Ixodida) of Central Europe; Wydawnictwo Naukowe Uniwersytetu Pedagogicznego: Kraków, Poland, 2013.

35. Wodecka, B.; Rymaszewska, A.; Skotarczak, B. Host and pathogen DNA identification in blood meals of nymphal Ixodes ricinus ticks from forest parks and rural forests of Poland. Exp. Appl. Acarol. 2014, 62, 543-555. [CrossRef] [PubMed]

36. Levin, M.L.; Nicholson, W.L.; Massung, R.F.; Sumner, J.W.; Fish, D. Comparison of the reservoir competence of medium-sized mammals and Peromyscus leucopus for Anaplasma phagocytophilum in Connecticut. Vector Borne Zoonotic Dis. 2002, 2, 125-136. [CrossRef]

37. Sjöstedt, A.; Eriksson, U.; Berglund, L.; Tärnvik, A. Detection of Francisella tularensis in ulcers of patients with tularemia by PCR. J. Clin. Microbiol. 1997, 35, 1045-1048. [CrossRef] [PubMed] 
38. Labruna, M.B.; Pacheco, R.C.; Nava, S.; Brandão, P.E.; Richtzenhain, L.J.; Guglielmone, A.A. Infection by Rickettsia bellii and Candidatus "Rickettsia amblyommii" in Amblyomma neumanni ticks from Argentina. Microb. Ecol. 2007, 54, 126-133. [CrossRef] [PubMed]

39. Kumar, S.; Stecher, G.; Li, M.; Knyaz, C.; Tamura, K. MEGA X: Molecular Evolutionary Genetics Analysis across Computing Platforms. Mol. Biol. Evol. 2018, 35, 1547-1549. [CrossRef]

40. Tamura, K. Estimation of the number of nucleotide substitutions when there are strong transition-transversion and $\mathrm{G}+\mathrm{C}-\mathrm{content}$ biases. Mol. Biol. Evol. 1992, 9, 678-687. [CrossRef] 